DOI: https://doi.org/10.18371/fp.3(35).2019.190169

JEL Classification F43, F63, L80, O10

\title{
THE THEORY AND PRACTICE OF CREATIVE ECONOMY IN THE CONDITIONS OF DIGITALIZATION
}

\author{
PANTIELIEIEVA Nataliia \\ Dr.Sc. in Economics, PhD in Technical sciences, Assoc. Prof., \\ Banking University, Cherkasy Institute \\ ORCID ID: https://orcid.org/0000-0001-6457-6912 \\ e-mail:nnpanteleeva2017@gmail.com
}

\author{
ARUTIUNIAN Lilit \\ student, Banking University, Cherkasy Institute \\ e-mail: arutyunyan.lilit17@gmail.com
}

\begin{abstract}
The article deals with the prerequisites and generalizes approaches to defining the concept of "creative economy"; on the theoretical basis and practices of creative economy in leading countries of the world an internals and the main principles of its development are identified; genesis of the concept of creative economy is considered; goals, policies, implementation practices in countries around the world are systematized. The position of Ukraine and other countries of the world in the ranking of the global index of creativity are characterized; features of the creative industry in Ukraine are revealed; index of activity of the creative industry of Ukraine is calculated, which indicates a stable tendency of its development. Potentials of digital technologies, in particular, artificial intelligence, augmented and virtual reality, blockchain technology, to the transformation of creative economy are grounded.
\end{abstract}

Keywords: creativity, creative economy, creative industries, creative capital, the index of creativity, index of activity of creative industry, digital technology.
Аннотация. $B$ статье исследованы предпосылки и обобщены подходы к определению понятия «креативная экономика»; на основе теоретических положень и практики креативной экономики в ведущих странах мира выявлено интерналии и визначено основные принцииь ее развития; рассмотрено генезу концепции креативной экономики, систематизированы цели, политику, практику реализачии в странах мира; охарактеризовано позииию стран мира и Украинь в рейтинге глобального индекса креативности; раскрыто особенности креативной индустрии в Украине; рассчитан коэффициент активности креативной индустрии Украины, который свидетельствует об устойчивой тенденции ее развития; обоснованно потенциальные возможности цифровых технологий, в частности, искусственного интеллекта, расширенной и виртуальной реальности, технологии блокчейн, к трансформачии креативной экономики.

Ключевые слова: креативность, креативная экономика, креативные индустрии, креативный капитал, индекс креативности, индекс активности креативной индустрии, циировые технологии. 
Introduction. In the twenty-first century, socio-economic systems demonstrate an evolutionary transformation due to the spread of innovation, digital technology and high-tech products, as well as the rise in importance of intellectual capital. In such a post-industrial economic space, the evolutionary economy of the creative industries or the creative economy is becoming increasingly important. For a long time, the dynamics of consolidation of innovations and economy prevailed in market models. The creative industries did not fit into such models; for the most part they were viewed through the lens of cultural heritage and individual creativity, supported by state protectionism, normative and institutional means as a separate sector; did not receive a proper assessment of their ability to become self-important, in order. The post-industrial paradigm opens a new perspective on the creative economy, in particular, its contribution to the dynamics of the innovation system, the potential ability to generate and stimulate creative ideas, realizing and disseminating them as innovations in socio-cultural and economic systems. It should be noted that the spread of digitalization trends in all sectors of the economy has intensified the process of the disappearance of individual and / or replacement of a sustainable list of professions in favor of those where the main competences are based on creativity. The creativity of human capital reveals additional opportunities for economic, innovative and technological development. Therefore, along with external effects, such as the formation of humanistic values, personal and national identity, emotional intelligence, the main economic value of the creative economy is its ability to be a powerful sector of the national economy and one of the drivers of economic growth along with science and technology.

\section{Literature Review and Problem} Statement. Theoretical and methodological foundations of the formation of the model of post-industrial development of socio-economic systems, as well as the scientific substantiation of the emergence of the phenomenon of creative economy, were paid considerable attention by foreign and domestic scientists, in particular: S. Archierev, D. Bell, T. Bozhidarnik, P. Bourdieu, M. Castels, A. Chukhno, V. Dementyev, P. Drucker, F. Fukuyama, A. Galchinsky, V. Geyets, A. Gritsenko, J. Hawkins, D. Hesmondonds, P. Leonenko, M. Matthews, J. Potts, V. Savchuk, V. Seminozhenko, A. J. Scott, V. Tarasevich, E. Toffler, D. Trosby, N. Vasylik, Y. Zaitsev, M. Zgurovsky et al. Along with the formation of the theoretical basis for the development of creative economics, a separate area of applied research was the development of scientific and methodological approaches to measuring and assessing the level of growth of creative industries and creative capital. So it is worth noting the scientific works of such researchers as G. Brown, R. Florida, J. Hagle, D. Himes, C. Landry, J. Shapiro, Y. Sotnikova and others. At the same time, the dynamics of transformational changes in the economic environment, varying degrees of readiness and the perception of the creative economy as a driver of growth at the level of individual countries of the world necessitate further scientific research.

The purpose of the research is to identify the prerequisites and generalize the theoretical foundations of the emer- 
gence and formation of creative economy, to study the state of creative economy on the index "technology-talentstolerance" in the countries of the world, as well as in Ukraine, evaluation of the activity of the domestic creative industry.

Results of the Research. The origins of the creative economy phenomenon lie in the scientific basis of post-industrial theory and the pluralism of the scientific points of view of its founders, in particular, D. Bell [1], M. Castels [2], B. Lundwall [3], E. Toffler [4]. The scientists unanimously recognized knowledge as the result of intellectual work and a source of innovation, emphasizing in this aspect the importance of cultural and value priorities, among which emphasized the importance of the development of social institutions, the value system, mass culture, science and education.

Not detailing the various approaches to the interpretation of the concept of "creative economy", we note that they all determine its goals, creative and intellectual resource base (J. Hawkins [5, p.10], R. Florida [6, p.13]), significance for the main factors of production (S. Novikova $[7$, p.177]), specificity of socio-economic relations based on creative ideas and innovative process (O. Stepanov and M. Savina [8, p.6 ]).

The study of theoretical foundations and practices of creative economy in the leading countries of the world revealed the following internals of its development: 1) formation of new socioeconomic or material-economic relations between creative entities and / or classical economic agents; 2) key factors and sustainable interconnection and interplay between them - human capital, innovation, investment, market demand and an effective management system, digital technologies, that change the forms of creation, distribution and sale of creative economy products; 3) structural elements: creative entities capable of generating creative ideas; objects in the form of the potential of a creative idea realized in creative products, a creative environment for generating ideas, creative technologies for creating and commercializing a creative product.

In our opinion, the creative economy is based on the following principles:

- versatility in creativity; freedom of expression and attitude to the creative idea;

- unlimited creative resources and intellectual and creative capital for economic development;

- convergence of science and art, creativity and innovation;

- productivity - the ability to create a highly intellectual and creative product of work, which acquires new features individual participation of creative personality in economic processes, orientation to knowledge, professionalism, creativity, information and digital competencies, and intellectual property becomes the main value.

Defining the creative economy as a driver of development, the countries of the world consider it an important component of economic policy and implement it through national, regional and local strategies (Table 1). 
Table 1

Characteristic of economic policy of creative economy

of some countries of the world

\begin{tabular}{|c|c|c|c|}
\hline Country & $\begin{array}{l}\text { Document name, } \\
\text { year of adoption }\end{array}$ & Basic principles, tasks, results & The role of government \\
\hline $\begin{array}{l}\text { South } \\
\text { Korea }\end{array}$ & $\begin{array}{l}\text { Creative Economy } \\
\text { Action Plan and } \\
\text { Creative Economy } \\
\text { Ecosystem Building } \\
\text { Measures (2013) }\end{array}$ & $\begin{array}{l}\text { distribution in the society of "cre- } \\
\text { ative imagination"; cross-industry } \\
\text { convergence; created new con- } \\
\text { vergence products and services; } \\
\text { new "creative" quality for sus- } \\
\text { tainable growth }\end{array}$ & $\begin{array}{l}\text { support for new types of fair } \\
\text { competition organization; } \\
\text { financing models; fair regula- } \\
\text { tion; protection of intellectual } \\
\text { property }\end{array}$ \\
\hline Japan & $\begin{array}{l}\text { Cool Japan Strategy } \\
\text { (2010) }\end{array}$ & $\begin{array}{l}\text { stimulating the profitability of } \\
\text { potential growth areas (anima- } \\
\text { tion, content, fashion, food and } \\
\text { tourism) }\end{array}$ & $\begin{array}{l}\text { promotion of creative think- } \\
\text { ing, investment in intangible } \\
\text { assets, elimination of cultural } \\
\text { closure, etc. }\end{array}$ \\
\hline Singapore & $\begin{array}{l}\text { Creative Industries } \\
\text { Development } \\
\text { Strategy (2002) }\end{array}$ & $\begin{array}{l}\text { creation the economy of } \\
\text { knowledge, educating a work- } \\
\text { force capable of creating high } \\
\text { value-added products, creating a } \\
\text { "talent network", transforming it } \\
\text { into an information and intellec- } \\
\text { tual and multimedia international } \\
\text { hub, full accessibility and use of } \\
\text { ICT (free of charge). }\end{array}$ & $\begin{array}{l}\text { creation an institutional base, } \\
\text { investing in the creative and } \\
\text { ICT sectors, stimulating de- } \\
\text { mand and new markets, etc. }\end{array}$ \\
\hline Australia & $\begin{array}{l}\text { Australia's New In- } \\
\text { dustries Strategy of } \\
\text { 21st Century (2008), } \\
\text { Creative Australia } \\
\text { (2013) }\end{array}$ & $\begin{array}{l}\text { recognition of the importance of } \\
\text { the creative industries, education } \\
\text { and investment; national broad- } \\
\text { band network for the economic } \\
\text { development }\end{array}$ & $\begin{array}{l}\text { creating a creative environ- } \\
\text { ment through legal, political } \\
\text { and fiscal strategies, support- } \\
\text { ing public-private partner- } \\
\text { ships, ensuring productive } \\
\text { synergies of communications, } \\
\text { IT and arts }\end{array}$ \\
\hline
\end{tabular}

Source: formed by the authors on the basis of [14, 15]

In the EU, creative economics is understood to mean "an industry based on individual and collective creativity, skill and talent. The creative economy is able to shape well-being and working places through the creation and use of intellectual property, and creative personalities occupy a central place in these processes"[9]. The Creative Europe Program (2014-2020), that was adopted in the EU, envisages supporting the cultural, creative and audiovisual sectors. We see that the creative economy is realized through the unification and development of creative industries.
The assessment of the level of creativity of the countries of the world is carried out on the basis of a global index of creativity, which is integral of three indicators - technology, talents, tolerance ("3T"). In particular, in the 2015 ranking, the leader in the Top 10 was Australia (0.97), and the last in the top ten were the Netherlands (0.889).

For example, the UK was ranked 12th in the rating of 0.881 . In 2018, employment in the creative economy rose to 2.04 million people $(6.2 \%$ of the total employed population against $5.2 \%$ in 2011), and the share of GDP is almost $10 \%(£ 102 \mathrm{bn})$ and $14.6 \%$ of GVA. Ex- 
ports of creative services account for $11 \%$ of total UK services [11].

The creative economy sector of Estonia (33th place in rating - 0.625), whose spheres are architecture, audiovisual art, design, visual arts, publishing, cultural heritage, art, entertainment software, music, advertising, in 2015-2016 numbered 30,681 thousand people $(4.8 \%$ of the total employed population), 9098 enterprises and institutions (11.6\% of the total number of enterprises), which have generated a total income of EUR 1481 million (2.9\% of GDP) [9].

Ukraine has taken 45th position out of 139 with a rating of 0.518 , indicators of "technology - talents - tolerance" make $43,24,105$ respectively, so the most problematic is the indicator of tolerance. But if we compare its position on the sub-index "talents", it is equal to 24 , the best values were shown by Spain (19), Great Britain (20), Ireland (21), Latvia and Sweden - 22. The share of the creative industries sector in the GDP of
Ukraine is 4.4\% (UAH 105 billion), employing about 460 thousand people. Ukraine is a member of several international programs such as Culture and Creativity: EU and Eastern Partnership (2015-2018), Creative Europe (20142020), Culture Bridges (2017-2020) and Creative Spark [10].

Based on the research by Yu.V. Sotnikova, an assessment of the level of creativity of the regions of Ukraine in 2016 by the index "3T" was carried out (Table 2). The clustering of Ukrainian regions showed that under-creativity regions accounted for $46 \%$ (11 regions) and leaders $-8.3 \%$ (2 regions) [12].

Ukraine's creative industry covers 12 industries. In 2018, compared to 2013, it generated $3.86 \%$ (UAH 97 billion) of value added versus $2.97 \%$ (UAH 30.8 billion), the number of economic entities -175 thousand $(9.5 \%$ of the total number) against 97 thousand (5.6\%), employed workers -309.5 thousand $(3.6 \%)$ against 252.3 thousand (2.5\%) [13].

Table 2

Assessment of the level of creativity of Ukrainian regions

\begin{tabular}{|c|c|}
\hline Indicator & Regions that are in the Top 3 \\
\hline \multicolumn{2}{|c|}{ Talent Index } \\
\hline Creative class index & Kharkiv, Dnipropetrovsk, Kiev \\
\hline Index of human capital and scientific talent & Kharkiv, Dnipropetrovsk, Lviv \\
\hline \multicolumn{2}{|c|}{ Technology Index } \\
\hline Index of investment in science & Kharkiv, Dnipropetrovsk, Rivne \\
\hline Innovation Index & Kharkiv, Cherkasy, Poltava \\
\hline \multicolumn{2}{|c|}{ Tolerance Index } \\
\hline Value Index & Dnepropetrovsk, Ternopil, Sumy \\
\hline Self-expression index & Kharkiv, Dnipropetrovsk, Kiev \\
\hline
\end{tabular}

Source: formed by the authors on the basis of [12]

To determine the spread of the creative economy in Ukraine, we calculate the activity factor of the creative industry by the following formula:

$$
K C I=\sqrt[4]{S V A * P C * S B E * S E},
$$

where, SVA is the share of value added created by the creative industry; PC - 
the share of personnel costs involved in the creative economy; SBE - the proportion of entities; SE - the share of employed in the creative industry.

Activity index is measured on a scale from 1 to 10 , where a value of up to 4 points indicates a lack of development, from 4 to 6 points - a stable development, and more than 6 points - an active development of the creative industry.
The dynamics of the calculated index of activity of the creative industry of Ukraine shows that it had insufficient activity during 2013-2016 (Fig. 1). But since 2017, the values of index have been characterized by a steady upward trend, indicating that the creative industry has a steady upward trend.

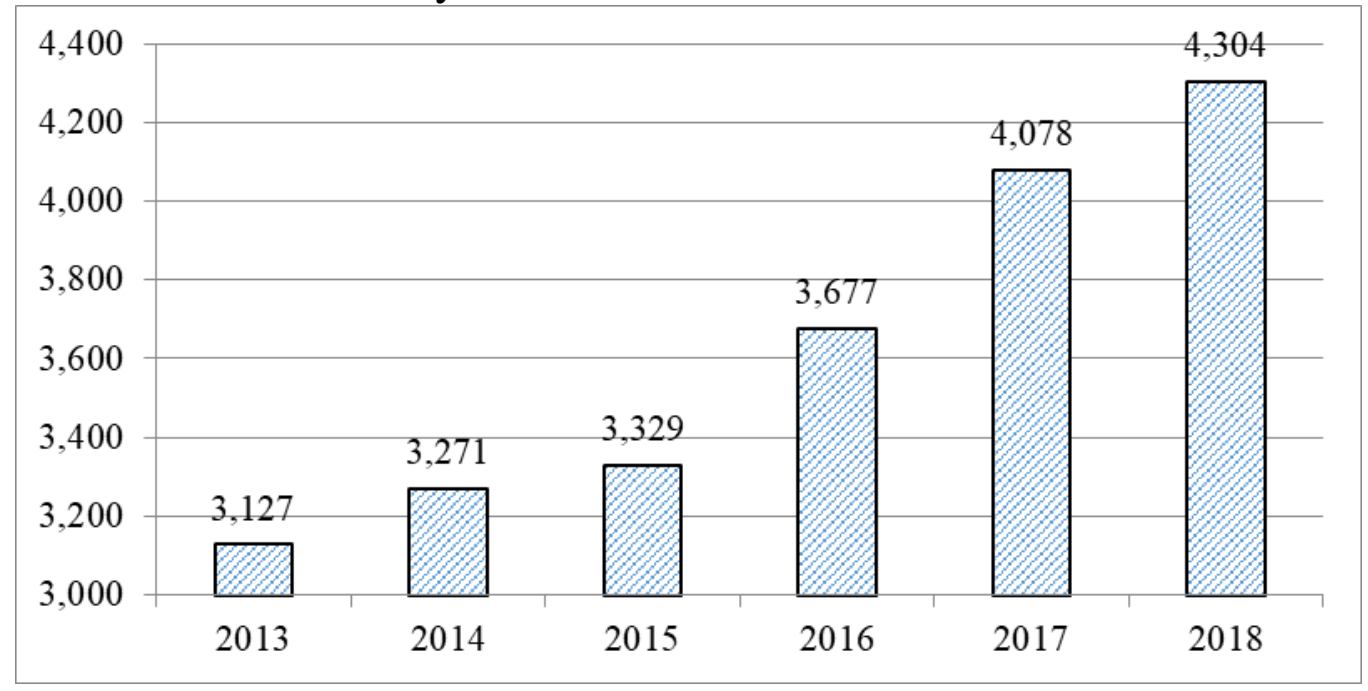

Fig. 1 Dynamics of the Ukrainian creative industry by activity factor Source: author's own calculation

Dissemination of digital technologies is already transforming the industries of modern economy, opening up new opportunities and producing legal, economic and structural problems. The creative economy is also beyond the reach, as digital technologies are changing the process of creating a creative product, the means and channels of its promotion, the environment for forming new communication links between its producers and consumers.

The most well-known is the technology of virtual and augmented reality, which expands the possibilities of visualization of information - motion pictures, animation, computer games, museum and exhibition activity, tourist industry and more.

Artificial intelligence technologies are used extensively in the advertising industry, allowing to automate and create dynamic, data-driven content, banners, advertisements that can be personalized or customized for a particular consumer segment, or integrated into a single, intelligent city system. Artificial Intelligence can create personalized video content according to searches, regardless of audience size. Replacing partnerships with digital marketing agencies comes with machine learning. The impetus for this transition is the desire of companies to reduce costs and increase advertising effectiveness, increase customer base and 
sales. Machine learning has already proven its capabilities in the music and arts, fashion industries, journalism (news coverage, weather forecasting, event notes, etc.) and copywriting (writing slogans, generating product descriptions) and more. The proliferation of artificial intelligence and machine learning in the creative industries will continue, as they allow to minimize routine operations, identify trends more quickly, accelerate the creative process, relying on the analytical processing of large amounts of information.

Another technology that is catching the attention of the creative industries is blockchain technology, which is familiar to most through bitcoin cryptocurrency. Blockchain services allow to create and maintain a reputation system, enter into smart contracts, make transparent P2P transactions, crowdfunding, dynamically generate effective pricing and monetize creative products, and earn a fair income. This technology is in demand in the music industry. Platforms like Stem (generating revenue from using music content in YouTube, Apple Music, etc.), Bittunes
(Bitcoin Fan Share), Soundcheck (to fund artists through Ethereum smart contracts), Ujo (system of registration of works on the Ethereum blockchain with further possibility of listening and downloading), Mycelia (eliminates intermediaries), Typerium (improves protection of intellectual property) [17] are already used nowadays.

Conclusions. Thus, the growth rate of the creative economy in the countries of the world, the high share of value added and the increase in the number of people employed in all its sectors, even during the economic crisis and recession, eloquently confirm its ability to become a new driver for the development of national economies. In Ukraine, some steps have already been taken in this area, but considerable creative potential requires efforts to be made in a quality and effective way. The impetus for the further development of the creative economy may be digital technologies that lead to transformation and open up new opportunities for the creative environment and the means of creative, innovative-oriented production.

\section{References}

1. Bell, D. (2004). Grjadushhee postindustrial'noe obshhestvo. Opyt social'nogo prognozirovanija [The upcoming post-industrial society. Social Forecasting Experience] [in Russian].

2. Kastel's, M. (2000). Informacionnaja jepoha: jekonomika, obshhestvo i kul'tura [The Information Age: Economics, Society, and Culture]. GU VSHE [in Russian].

3. Lundvall, B. (2010). National Systems of Innovation: Toward a Theory of Innovation and Interactive Learning.

4. Toffler, A. (1980). The Third Wave. 
5. Hokins, Dzh. (2011). Kreativnaja jekonomika. Kak prevratit' idei v den'gi [Creative economy. How to turn ideas into money] [in Russian].

6. Florida, R. (2011). Kreativnyj klass: ljudi, kotorye menjajut budushhee. [Creative class: people who change the future] [in Russian].

7. Novikova, S.K. (2019). Kreativnaja jekonomika kak drajver rosta: mirovoj i rossijskij opyt [Creative economy as a driver of growth: global and Russian experience]. Novye tehnologii - New Technologies, 2(48), 175-182 [in Russian].

8. Stepanov, A.A. \& Savina, M.V. Kreativnaja jekonomika: sushhnost' i problemy razvitija. [Creative economy: essence and problems of development]. Retrieved from: https://cyberleninka.ru/article/n/kreativnaya-ekonomika-suschnost-i-problemy-razviti ya [in Russian].

9. Kreativnaja jekonomika. Ministerstvo kul'tury Jestonii. [Creative economy. Ministry of Culture of Estonia]. Retrieved from: https://www.kul.ee/ru/sferydeyatelnosti/kreativnaya-ekonomika [in Russian].

10. Jevropejs'ka Komisija spil'no z Minkul'tury provely seminar TAIEX shhodo jevropejs'kyh praktyk rozvytku kreatyvnyh industrij [European Commission, together with the Ministry of Culture, hold a TAIEX seminar on European practices for the development of creative industries]. Retrieved from: https://www.kmu.gov.ua/news/ yevropejska-komisiya-spilno-z-minkulturi-proveli-seminar-taiex-shchodo-yevropejsk ih-praktik-rozvitku-kreativnih-industrij [in Ukrainian].

11. Britain's creative industries break the $£ 100$ billion barrier. Retrieved from: https://www.gov.uk/government/news/britains-creative-industries-break-the-100-billi on-barrier.

12. Sotnikova, Ju.V. (2016). Kreatyvna ekonomika v Ukrai'ni: real'nist' chy perspektyva? [Creative Economy in Ukraine: Reality or Perspective?]. Visnyk Nacional'nogo universytetu vodnogo gospodarstva ta pryrodokorystuvannja. Ekonomichni nauky Bulletin of the National University of Water Management and Nature Management. Economic sciences, 3, 178-189 [in Ukrainian].

13. Kreatyvni industrii' v Ukrai'ni. Statystyka 2013-2018 [Creative Industries in Ukraine. 2013-2018 statistics]. Retrieved from: http://bit.ly/CU19-st2 [in Ukrainian]. 14. Creative Australia. National Cultural Policy. Retrieved from: https://www.nck. $\mathrm{pl} /$ upload/ attachments/302586/creativeaustraliapdf2.pdf. 
15. Economic contributions of Singapore's creative industries Retrieved from: https://www.ico-d.org/database/files/library/singapore.pdf.

16. Creative Disruption: The impact of emerging technologies on the creative economy. Retrieved from: https://www.mckinsey.com/ /media/mckinsey/indus tries/technology\%20media\%20and\%20telecommunications/media\%20and\%20entert ainment/our\%20insights/how\%20do\%20emerging\%20technologies\%20affect\%20the $\% 20$ creative\%20economy/creative-disruption.ashx.

17. Blokchejn i muzykal'naja industrija [Blockchain and the music industry]. Retrieved from: https://decenter.org/ru/blokcheyn-i-muzykalnaya-industriya [in Russian]. 